\title{
THE EFFECT OF EXPERIENTIAL MARKETING ON EXCELSO CAFE CUSTOMER LOYALTY IN CENTRAL JAKARTA 2019
}

\author{
By: \\ Rina Ayu Vildayanti \\ The Faculty of Economics and Business \\ Budi Luhur University \\ Email: \\ rina.ayuvildayanti@budiluhur.ac.id
}

\begin{abstract}
This study aimed to look at the effect of experiential marketing on Excelso cafe customer loyalty in Central Jakarta 2019. The research methodology used is a quantitative method with cross-section data and primary data obtained from questionnaires. The sampling technique using a purposive sampling method with the data in 2019. The data analysis technique used is multiple linear regression to test the validity, reliability test, classic assumption test (multicollinearity test, heteroscedasticity test), and hypothesis testing $t$-statistic and $f$-statistic to examine the effect together with a significance level of 5\%. The results of this study indicate that in a partial sense, feel, think, and act positive and significant impact on customer loyalty, while related variables have a negative effect but not significant on customer loyalty. Meanwhile, simultaneous independent variable sense, feel, think, act, and relate togetherly have a significant relationship to the dependent variable which is customer loyalty. The coefficient of determination from this study showed that the number of $71.96 \%$ of the variation of the independent variable sense, feel, think, act, and relate can explain the variation of the rise and fall dependent variable customer loyalty by $71.96 \%$, while the remaining $28.04 \%$ influenced by another independent variable.
\end{abstract}

Keywords: Act, Customer Loyalty, Experiential Marketing, Feel, Relate, Sense, Think.

\section{A. INTRODUCTION}

The development of the business world is currently growing rapidly and competition between similar companies is also tight. Every company leader wants his company to be the best among other companies. The company leaders are competing to create effective strategies to realize the best companies and can survive in the existing competition. Every business person is required to have a high sensitivity to every change that occurs. Marketing must also be able to answer what customers want and need so they can be satisfied. The trend in marketing that is developing now is more directed to the formation of experiences for customers. 
Excelso is the largest coffee shop in Indonesia. Excelso which is under the auspices of PT. Excelso Multi Rasa, which was founded in 1990 and is a subsidiary of Kapal Api Global, the largest coffee bean producer in Indonesia, was established in 1927. The subsidiary of Kapal Api Group includes PT. Santos Jaya Abadi which engages in the production of coffee, both coffee beans and ground coffee with brands including Kapal Api, Excelso, ABC, Good Day, Santos, Kapten, and Ya, PT. Sulotco Jaya Abadi which engages in coffee plantations located in Toraja, South Sulawesi. Is the largest private coffee plantation in the Sulawesi region, the harvest is not only used for company needs but also export purposes, PT. Excelso Multirasa which engages in the coffee shop industry with the brand 'Excelso', and marketing coffee beans to hotels, restaurants, and cafes, PT. Agel Langgeng engages in the production of sweets with brands including Relaxa, Travela, Yesco, and Espresso and PT. Fastrata Buana which engage in the distribution in the territory of Indonesia, especially for Kapal Api Group products.

The first Excelso cafe was opened in September 1991 at Plaza Indonesia, Jakarta to support the new Excelso Coffee brand created by PT. Santos Jaya Abadi. Excelso Coffee is made and marketed still in the form of coffee beans with a reason to meet the needs of middle and upper-class coffee and to remove the image of mixed coffee (coffee mixed with corn), because the highest quality coffee is still in the form of beans and the only ground when brewed, so it's awake. Excelso cafe was established to support the marketing and image that Excelso Coffee was about to create. By choosing the upper-middle-class market, Excelso Coffee can be found in supermarkets and at Excelso cafe itself. Excelso cafe continues to grow in the number of outlets, service concepts, designs, and types of coffee, food and beverages served. This is in line with the demands of the people who have made coffee a part of their lifestyle. Excelso also developed the concept of its services tailored to the potential of existing locations and the purchasing power of the surrounding community. The concept of this service is coffee, coffee, and coffee. Whatever the concept is run, coffee remains the main menu at Excelso cafe.

Experiential marketing is a marketing concept by focusing on providing experiences that lead to buying behavior (Rahardja \& Anandya, 2010). The concept of experiential marketing is done by marketers to offer products and services by stimulating the emotional elements of customers that produce a variety of experiences for customers (Rizal, 2016). Sense, feel, think, act and relate are used as guidelines, making experiential marketing different from traditional concepts, focusing on customer experience, perceiving consumption as experience in an overall manner overall, treating customers as rational and emotional beings. Stimulate sense elements aimed at feelings to create experiences through sense, feel aimed at positive feelings and emotions that arise, think aimed at intellectuals to create awareness (cognitive), experience to solve problems that involve customers in it, activities aimed at influencing physical experience, lifestyle and interaction, relate is used to attract customers so that customers can feel satisfied and loyal.

The business strategy that is developing at this time is a strategy that links the emotional aspects of customers with the brand, community, and corporate brand through the experience felt by customers (Iglesias et al., 2011). In experiential marketing, the company is not only oriented on features and benefits but also 
prioritizes customer emotions by providing facilities that can provide satisfaction for customers, so that a memorable experience is achieved that makes customers repeat experiences that are loyal to the company's services and even want to spend more money to enjoy new experiences using other facilities offered by the company, it can be said that experiential marketing is very important to provide a variety of good experiences for customers who aim to create customer loyalty, such as the wishes of every company, one of which is Excelso cafe.

Customer loyalty is an effort to keep old customers must receive greater priority compared to new customers. That is easier to retain existing customers than attracting new customers and losing customers can be disastrous in a mature market (Tsai et al., 2010). Therefore, customer loyalty based on pure and continuous satisfaction is the biggest asset owned by Excelso company is the largest coffee shop in Indonesia. Excelso is under the auspices of PT. Excelso Multi Rasa was established in 1990 and is a subsidiary of Kapal Api Global, the largest coffee bean producer in Indonesia, which was founded in 1927. Excelso cafe was first opened at Plaza Indonesia. The number of Excelso cafes has now reached more than 126 outlets spread in more than 30 major cities in Indonesia, namely: Jakarta, Solo, Manado, Palembang, Bogor, Surabaya, Balikpapan, Bandung, Malang, Medan, Yogyakarta, Bali, Pekanbaru, Semarang, Makassar, Batam (https://excelsocoffee.com/about-us/, n.d.).

\section{B. LITERATURE REVIEW}

\section{Experiential Marketing}

An experience is an event that is personal in response to the stimulation provided by the seller/manufacturer (Schmitt, 2011). In the experiential marketing strategy, the customer not only requests quality goods but also wants emotional benefits, in the form of a memorable experience that is a memorable experience that is not forgotten, a positively unique experience, a holistic experience through all five senses. The experiential marketing strategy will shift the traditional marketing approach that emphasizes the features and benefits of rational products and customers. As a result, traditional approaches that do not yet involve elements of emotion and experience are vulnerable strategies, will not be able to survive, and will be weakened in the face of rivals (Buchari, 2014).

Experiential marketing is different from traditional marketing. The characteristics of traditional marketing emphasize the functional features and benefits of the product, while experiential marketing considers the features and benefits as given, something that is so more important for the experience of experience. Traditional marketing is not too concerned with the state of the product and the level of competition is still lacking, and the customer is very rational while experiential marketing considers that consumption activities are a comprehensive experience and the customer is rational and emotional. The emotional sense of the customer must be awakened and given valuable experience. Thus it can be said that experiential marketing is very important to create various experiences for customers (Alkilani et al., 2013) and experiential marketing has a positive effect on customer satisfaction and loyalty (Walter et al., 2013). Experiential marketing is a new 
invention to overcome customer dissatisfaction with producers who initially gave grandiose promises but ultimately were very disappointing, there were no satisfying experiences.

\section{Customer loyalty}

Customer Loyalty is a deeply held commitment to rebuy or patronize a preferred product or service consistently in the future, despite situational influences and marketing efforts with the potential to cause switching behavior (Oliver, 2010). From this definition, it can be seen that loyalty is the commitment of customers to stay in-depth to re-subscribe and satisfied or re-purchase selected products/services consistently in the future, even though the influence of the situation and marketing efforts have the potential to cause behavior change. Customer-oriented marketing is marketing that emphasizes satisfying the needs and desires of customers (Sugianto \& Sugiharto, 2013). Satisfied customers will have an emotional bond with the products or services consumed and tend to be loyal to the company (Kotler, 2019).

Loyalty is defined as non-random purchased expressed over time by some decision-making units (Griffin, 2008). Loyalty refers more to the manifestation of the behavior of the decision-making units to make continuous purchases of goods/services of a chosen company. Customer loyalty is an effort to keep old customers must receive greater priority compared to new customers (Zichermann \& Linder, 2010). Furthermore, Griffin states the benefits to be gained by a company if it has loyal customers, including can reduce marketing costs (because the cost to attract new customers is more expensive), can reduce transaction costs, can reduce customer turn over costs (due to fewer customer replacements), can increase crosssales, which will enlarge the company's market share, encouraging more positive word of mouth, assuming that loyal customers also means those who are satisfied and can reduce failure costs (replacement costs). Overall satisfaction dan loyalty based on purchases and the experience of consuming goods and services (Chen, 2012).

The characteristics of customer loyalty itself are important assets for the company, this can be seen from the characteristics they have (Halim et al., 2014), loyal customers have the following characteristics make regular purchases (makes regular repeat purchases), but outside the product/service line (purchases across products or service lines), recommend other products and demonstrate immunity from the appeal of similar products from competitors. In designing and creating loyalty related to the customer experience that customer loyalty cannot be created just like that, but must be designed by the company (Gee et al., 2008). The following are the stages of designing loyalty: define customer value, design the branded customer experience, equip people, and deliver consistently, sustain, and improve performance.

The process of a prospective customer is a loyal customer of the company is formed through several stages (Munandar, 2011), namely stages of loyalty according to Niegel Hill too, customer loyalty is divided into six stages. The stages are explained as follows includes suspect, prospect, customer, clients, advocates, dan partners, while Hermawan Kertajaya divides the stages of customer loyalty into 
five levels ranging from terrorist customers, transactional customers, relationship customers, loyal customer, and advocator customer (Kertajaya, 2010).

Sense, Through the five senses, creates sensory experiences through sight, touch, feeling, and smell, which gives the impression of beauty, pleasure, satisfaction, through stimuli, processes, and consequences or results obtained because of the stimuli and the process (Buchari Alma, 2014). Fee, Feelings touch inner feelings and emotions intending to arouse effective experiences, so there is a sense of joy and pride. Here the customer's mood and emotion must be considered. Moods can be obtained through special stimuli where customers are not aware of this, while emotions are deliberately pursued by the company, for example growing in love. Likewise emotions, there is a basic emotion, such as feelings of joy, anger, and complex emotion, such as the emergence of a sense of nostalgia (Buchari, 2014). Think, thinking creates cognitive aspects, problem-solving experiences. Thinking will appear in divergent and convergent thinking through surprise, intrigue, and provocation. A good mind will bring customers able to think positively, thus giving a positive opinion on products and institutions (Buchari, 2014). Act, act touches on experiences in lifestyle and interacts. The change in lifestyle is influenced by inspiration, spontaneous because of seeing the model. Customers will buy because of outside influences and opinions inside (Buchari, 2014). Relate, relation includes the five senses, feelings, think, and habits. This is an individual experience relating to other people in certain cultures, for example in cosmetics marketing, can create a fantasy in the opposite sex. So in this case there is a goal to associate individuals with something that is outside of themselves (Buchari, 2014).

\section{RESEARCH METHOD}

Based on the characteristics of the problems that discuss the effect of sense, feel, think, act and relate as experiential marketing variables on Excelso cafe customer loyalty in Central Jakarta 2019, this study using the quantitative method (quantitative research).

This research uses quantitative research and the type of data used in crosssection data. Where the source of data obtained by the process of distributing questionnaires distributed to customers who come and drink at Excelso cafe located in Central Jakarta, for a period of 3 (three) months from the period of June to August 2019. Primary data were obtained using a structured questionnaire to gather information from respondents. The score of each indicator variable obtained from filling out the questionnaire that has been distributed to respondents is the primary data source in this study using a Likert scale. Secondary data in this study is in the form of a customer data Excelso cafe in central Jakarta. The data is further processed to obtain the number of samples that will be used in this study.

The data collection techniques used in this study uses a purposive sampling technique which is the sample criteria used are as follows: customers who come and drink coffee at Excelso cafe Central Jakarta, customers who come and drink coffee at Excelso cafe Central Jakarta are minimal 5 (five) times a month and customers who come and drink coffee at Excelso cafe Central Jakarta who has enjoyed at least 3 (three) types of coffee drinks. The sample used in this study uses 
the sample calculation method with the formula proposed by Slovin (Yusuf, 2016) with the number of respondents of 100 customers Excelso cafe as respondents in this study.

The instrument used in this study is the data obtained from the distribution of questionnaires to respondents, then the data from the questionnaire results will be processed with a Likert scale to get the value of the variables consisting of sense, feel, think, act and relate. Multiple linear regression analysis can be used to obtain a comprehensive picture of the relationship between the dependent and independent variables as a whole both simultaneously and partially. The analytical tool in this study was translated into the variables used for multiple regression analysis as follows: customer loyalty variable $\mathrm{Y}$, sense variable $\mathrm{X}_{1}$, feel variable $\mathrm{X}_{2}$, think variable $\mathrm{X}_{3}$, act variable $\mathrm{X}_{4}$, and relate variable $\mathrm{X}_{5}$.

\section{RESULTS AND DISCUSSION}

\section{Overview and Research Objects}

Excelso is the largest coffee shop in Indonesia. Excelso which is under the auspices of PT. Excelso Multi Rasa, which was founded in 1990 and is a subsidiary of Kapal Api Global, the largest coffee bean producer in Indonesia, was established in 1927. The subsidiary of Kapal Api Group includes PT. Santos Jaya Abadi, PT. Sulotco Jaya Abadi, PT. Excelso Multirasa, PT. Agel Langgeng and PT. Fastrata Buana. The first Excelso cafe was opened in September 1991 at Plaza Indonesia, Jakarta to support the new Excelso Coffee brand created by PT. Santos Jaya Abadi. Excelso Coffee is made and marketed still in the form of coffee beans with a reason to meet the needs of middle and upper-class coffee and to remove the image of mixed coffee (coffee mixed with corn), because the highest quality coffee is still in the form of beans and the only ground when brewed, so it's awake.

Excelso cafe was established to support the marketing and image that Excelso Coffee was about to create. By choosing the upper-middle-class market, Excelso Coffee can be found in supermarkets and at Excelso cafe itself. Cafe Excelso continues to grow in the number of outlets, service concepts, designs, and types of coffee, food and beverages served. This is in line with the demands of the people who have made coffee a part of their lifestyle. Excelso also developed the concept of its services tailored to the potential of existing locations and the purchasing power of the surrounding community. The concept of this service is coffee, coffee, and coffee. Whatever the concept is run, coffee remains the main menu at Excelso cafe. The number of Excelso cafes has now reached more than 126 outlets spread in more than 30 major cities in Indonesia, namely: Jakarta, Solo, Manado, Palembang, Bogor, Surabaya, Balikpapan, Bandung, Malang, Medan, Yogyakarta, Bali, Pekanbaru, Semarang, Makassar, Batam.

This study aims to see how the effect of sense, feel, think, act, and relate as experiential marketing variables on Excelso cafe customer loyalty in Central Jakarta 2019. Data used is a cross-section data with the number of respondents of 100 customers Excelso cafe as respondents in this study. 


\section{Profile of Research Respondents}

The profile was obtained from the distribution of questionnaires of 100 (one hundred) respondents conducted during 3 (three) months from the period of June to August 2019.

\section{Gender, Age and Education of Respondents}

Gender, Age, and Education Data of Respondents were obtained from the distribution of questionnaires of 100 (one hundred) respondents from June to August 2019. The following Gender, Age, and Education Data of Respondents display in Table 1.

Table 1.

Gender, Age and Education of Respondents

\begin{tabular}{|c|c|c|c|c|c|c|c|c|}
\hline & $\begin{array}{c}\text { Male } \\
(\%)\end{array}$ & $\begin{array}{c}\text { Female } \\
(\%)\end{array}$ & $\begin{array}{c}<20 \\
\text { yo } \\
(\%) \\
\end{array}$ & $\begin{array}{c}21-30 \\
\text { yo } \\
(\%) \\
\end{array}$ & $\begin{array}{c}>30 \\
\text { yo } \\
(\%)\end{array}$ & $\begin{array}{c}\text { Highschool } \\
(\%)\end{array}$ & $\begin{array}{c}\text { Bachelor } \\
(\%)\end{array}$ & $\begin{array}{c}\text { Magister } \\
(\%)\end{array}$ \\
\hline Gender & 41 & 59 & - & - & - & - & - & - \\
\hline Age & - & - & 17 & 80 & 3 & - & - & - \\
\hline Education & - & - & - & - & - & 63 & 35 & 2 \\
\hline
\end{tabular}

\section{Data Analysis Results}

\section{Validity test}

Validity is the level of reliability and validity of the measuring instrument used. The instrument is said to be valid means to show the measuring instrument used to get the data is valid or can be used to measure what should be measured The validity test aims to find out if there are statements on the questionnaire that must be replaced because they are considered invalid. The following is a test of the validity of the statements contained in the variables: sense, feel, think, act, relate and customer loyalty, Excelso cafe in Central Jakarta in 2019.

All items of the questionnaire statements were submitted to 100 (one hundred) respondents. The value of $r$ table is obtained through df (degree of freedom $)=\mathrm{n}-2$, ie $\mathrm{df}=100-2=98$ with $\alpha=0.05$ or $5 \%$, then the value of $\mathrm{r}_{\text {table }}=$ 0.1966 . The results of the validity calculation of 5 (five) statement items for the customer loyalty variables appear to have a greater $\mathbf{r}_{\text {count }}$ value than the $\mathbf{r}_{\text {table }}$ so that all 5 statement items of customer loyalty variables are declared valid. The results of the calculation of the validity of the 4 (four) statement items for sense variables appear to have a greater $r_{\text {count }}$ value than $r_{\text {table }}$ so that the 4 statement items of sense variables are declared valid. The results of the calculation of the validity of the 4 (four) statement items for feel variables appear to have a greater $\mathbf{r}_{\text {count }}$ value so that the 4 statement items of feel variables are declared valid. The results of the calculation of the validity of the 4 (four) statement items for think variables appear to have $r_{\text {values }}$ greater than $r_{\text {table }}$ so that all 4 statement items of think variables are considered valid. The results of the calculation of the validity of the 4 (four) statement items for act variable appear to have $r$ values greater than $r$ table so that 
all 4 statement items of act variables are declared valid. The results of the calculation of the validity of the 4 (four) statement items for related variables appear to have a greater $r$ count value than the $r$ table so that all 4 statement items of related variables are declared valid.

\section{Reliability Test}

Reliability tests are carried out to determine the extent to which an instrument can provide relatively the same results if it is re-measured on the same subject. The following is the calculation of the reliability test of the instruments contained in the sense of the variable, feel, think, act, relate, and customer loyalty of Excelso cafe in Central Jakarta Tahun 2019.

From all statements of the instruments contained in the variables is the sense, feel, think, act, relate, and customer loyalty in the questionnaire submitted to 100 (one hundred) respondents. The value of $\mathrm{r}$ table is obtained through df (degree of freedom $)=\mathrm{n}-2$, ie $\mathrm{df}=100-2=98$ with $\alpha=0.05$ or $5 \%$, then the value of $\mathrm{r}$ table $=$ 0.1966 . The results of the calculation of the reliability of the 6 (four) instruments contained in the variables: sense, feel, think, act, relate and customer loyalty seems to have the value of $\mathbf{r}_{\text {count }}$ is greater than $\mathbf{r}_{\text {table }}$, so that the 6 instruments contained in the sense of the variable, feel, think, act, relate and customer loyalty in the questionnaire submitted can be declared reliable.

\section{Descriptive Statistics of Research Variables}

Where the results of the descriptive statistics provide a general description of the research object used as a research sample. The explanation describes the data through descriptive statistics which are expected to provide an initial description of the problem under study. Where descriptive statistics are more focused on the highest value, lowest value, average, and standard deviation of each variable studied: sense, feel, think, act, relate, and customer loyalty. It can be concluded that the average value of customer loyalty of 100 respondents studied during the observation period was 13.47000 . The highest customer loyalty value is 20.00000 and the lowest customer loyalty value is 6.000000 . Where the standard deviation of the customer loyalty variable is 3.019984 .

The average value of sense from 100 respondents studied during the period was 10.17000. The value of sense (the highest sense is 16.00000 and the value of sense (the lowest sense is 5.000000. Where the standard deviation of sense is 2.045221. The average value of feel from 100 respondents studied during the observation period 2019 was 8.320000 . The highest feel value was 16.00000 and the lowest feel value was 4.000000 . Where the standard deviation of the feel variable was 2.624207. The average thinks the value of the 100 respondents were studied during the observation period was 12.04000. The highest value of think is equal to 16.00000 and the lowest value of think is 6.000000 . Where the standard deviation value of the think variable is 2.228919 . The average value of the act from 100 respondents studied during the observation period was 11.46000. The highest value of the act is 16.00000 and the lowest value of the act is 4.000000 . Where the standard deviation of an act is 2.512273. The average related value of the 100 
respondents studied during the observation period was 10.64000 . The highest value of relationships is 16.00000 and the lowest value of relationships is 4.000000 . Where the standard deviation of relating is 2,500586.

\section{Model Stability Test}

This test uses recursive least squares to determine whether the regression model parameters are stable in the study period.

\section{Linearity Test}

Linearity is an initial assumption that should exist in a linear regression model. Linearity tests can be easily done in simple linear regression, which aims to determine whether the selection of linear regression models is appropriate or not. This linearity test uses the Ramsey RESET (Regression Specification Error Test) to test whether or not the linear regression model is used in this study, the hypothesis used is as follows $\mathrm{H}_{0}$ : Regression Model is stable (linear) and $\mathrm{H}_{1}$ : Regression Model is unstable (non-linear), with under the condition: Probability value $\mathrm{F}_{\text {arithmetic }}>\alpha_{(0.05)}$ (Failure to reject $\mathrm{H}_{0}$ ) and Probability value $\mathrm{F}_{\text {arithmetic }}<\alpha_{(0.05)}$ (Reject $\mathrm{H}_{0}$, Receive $\left.\mathrm{H}_{1}\right)$.

Based on the Ramsey Reset Test, the probability value of $\mathrm{F}_{\text {arithmetic }}$ is 0.3991 . While the error rate in this study uses $\alpha_{(0.05)}$, it can be concluded that the $\mathrm{F}_{\text {count }}$ probability value is $0.3991>\alpha_{(0.05)}$. It means that it fails to reject $\mathrm{H}_{0}$ so that the parameters of the regression model in this study are stable or linear.

\section{Normality test}

Histogram test results appear to be symmetrical and if a line is formed at each point it will form a bell pattern that indicates the normal distribution pattern, besides Jarque-Bera conducted using Eviews 7 programs in this study produces a count of 1.732233 with a probability of 0.420582 . If seen based on the value of chi-squares using $\alpha_{(0.05)}$ and $\mathrm{df}=6$, then the value of chi-squares is equal to 12,592. With the basic decision making as follows: $\mathrm{H}_{0}$ : Residual variable in the regression model used is normally distributed and $\mathrm{H}_{1}$ : Residual variable in the regression model used is not normally distributed

Based on the results it appears that the statistical value of the Jarque-Bera test is $\mathrm{JB}=(2.831434)<\mathrm{X}_{2}=(12,592)$ or $\mathrm{P}_{\text {value }}=(0.242751)>\alpha_{(0.05)}$, so the null hypothesis fails to be rejected which means the residuals of the research model are normally distributed so that the $\mathrm{t}_{\text {test }}$ and the $\mathrm{F}_{\text {test }}$ can be done to see the significance of the model.

Based on the results of the normality tests that have been carried, the multiple regression calculations are obtained as follows where the results of regression testing are carried out using multiple regression analysis with time-series data, next from the regression will be tested classic assumptions which consist of Multicollinearity Test and Heteroscedasticity Test. 


\section{Classic Assumption Test}

Before multiple linear regression testing is carried out on the research hypothesis, it is first necessary to do a test to determine whether there is a violation of classical assumptions. Good hypothesis testing results are tests that do not violate the classical assumptions that underlie the multiple linear regression model. The classic assumptions in this study include the multicollinearity test and the heteroscedasticity test.

\section{Multicollinearity Test}

This multicollinearity test is used to test whether the regression model found a correlation between independent variables or in other words to see whether there is a linear relationship between the independent variables in multiple regression in the equation Y (CUSTOMER LOYALTY $)=\beta_{0}+\beta_{1}($ SENSE $)+\beta_{2}($ FEEL $)+\beta_{3}($ THINK $)+$ $\beta_{4}(\mathrm{ACT})+\beta_{5}(\mathrm{RELATE})+e$.

Testing of the presence or absence of multicollinearity is done using the correlation coefficient method between independent variables. If the correlation coefficient between independent variables is above 0.85 then it is assumed that there is multicollinearity in the model. Conversely, if the correlation coefficient between independent variables is below 0.85 , there are no symptoms of multicollinearity in the model. From the results of the correlation coefficient test between the independent variables, there is no multicollinearity between the independent variables of sense, feel, think, act, and relate. Where is the value of the correlation between the independent variables of sense, feel, think, act, and relate is valued below 0.85 .

\section{Heteroscedasticity Test}

To determine heteroscedasticity in research using white heteroscedasticity is one of the tests for residuals from regression results with OLS. With heteroscedasticity, estimates with OLS are still consistent, but the standard error is invalid. In this case, it means that the variance obtained is inefficient. The basis for decision making in this heteroscedasticity test is as follows $\mathrm{H}_{0}$ : There is no heteroscedasticity and $\mathrm{H}_{1}$ : There is heterecodasticity.

From the results of the Glejser Test, it can be seen that there is no heteroscedasticity problem in observations in this study. This can be seen in the Chi-Square probability value $(0.0436)>\alpha_{(0.05)}$. In the absence of the Heteroscedasticity problem, the OLS estimator continues to produce BLUE estimators because estimators still have minimum variants, meaning: 1) The standard error calculation of the OLS method can still be trusted. 2) The estimation interval and hypothesis test $t$ and $\mathrm{f}$ can still be used to evaluate the regression results.

\section{Regression Analysis Results}

After conducting the normality test and the classic assumption test, in this study the multiple regression equation form with the linear regression equation in this study becomes: $Y=\beta_{0}+\beta_{1} X_{1}+\beta_{2} X_{2}+\beta_{3} X_{3}+\beta_{4} X_{4}+\beta_{5} X_{5}+e$ (Y=Customer Loyalty; $\beta_{0}, \beta_{1}, \beta_{2}, \beta_{3}=$ Constant/Slope, $X_{1}=$ Sense, $X_{2}=$ Feel, $X_{3}=$ Think, $X_{4}=$ Act, $X_{5}=$ Relate 
and $e=$ random error (error term)). In analyzing the sense, feel, think, act and relate to customer loyalty, multiple regression analysis is used, which together the regression models are:

\section{$\mathrm{Y}_{(\text {CUSTOMER LOYALTY })}=\beta_{0}+\beta_{1(\text { SENSE })}+\beta_{2(\text { FEEL })}+\beta_{3(\text { THINK })}+\beta_{4(A C T)}+\beta_{5(\text { RELATE })}+e$}

Based on the results of the multiple regression analysis, the coefficients for the independent variables are obtained, Sense $=0.548656$, Feel $=0.341817$, Think=0.394601, Act $=0.138293$, and Relate $=-0.011953$, with intercept $/$ constant of -1.162404. So from these results the regression equation models obtained are:

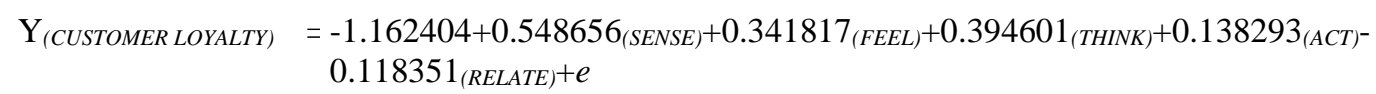

A constant value of -1.162404 illustrates that if sense, feel, think, act, and relate constantly affect customer loyalty, so customer loyalty will still be worth 1.162404 points. The calculation of the regression coefficient of sense variable seems to have a positive correlation on customer loyalty. This is evident in the coefficient value of the results of the regression analysis in which sense variables are 0.548656 , indicating a positive correlation to customer loyalty means that if sense increase by 1 point while the other variables remain, then customer loyalty value will increase by 0.548656 points. And vice versa, if the value of sense drops by 1 point while the other variables remain, then customer loyalty will also decrease by 0.548656 points.

The calculation of the regression coefficient of the feel variable seems to have a positive correlation on customer loyalty. This is evident in the coefficient value from the results of the regression analysis where the feel variable is 0.341817 , indicating a positive correlation to customer loyalty means that if the value of feeling rises by 1 point while the other variables remain, then the value of customer loyalty will increase by 0.341817 points. And vice versa, if feel value drops by 1 point while other variables remain, then customer loyalty will also decrease by 0.341817 points.

The calculation of the regression coefficient of the think variable seems to have a positive correlation on customer loyalty. This is evident in the coefficient value from the results of the regression analysis where the think variable is 0.394601 , indicating a positive correlation to customer loyalty means that if the value of think rises by 1 point while the other variables remain, then the value of customer loyalty will increase by 0.394601 points. And vice versa, if think value drops by 1 point while the other variables remain, then customer loyalty will also decrease by 0.394601 points.

The calculation of the regression coefficient of the act variable seems to have a positive correlation on customer loyalty. This is evident in the coefficient value from the results of the regression analysis where the act variable is 0.138293 , indicating a positive correlation to customer loyalty means that if the value of act rises by 1 point while the other variables remain, then the value of customer loyalty will increase by 0.138293 points. And vice versa, if act value drops by 1 point while the other variables remain, then customer loyalty will also decrease by 0.138293 points. 
The calculation of the regression coefficient of the related variable seems to have a negative correlation on customer loyalty. This is evident in the coefficient value from the results of the regression analysis where the related variable is 0.011953 , indicating a negative correlation to customer loyalty means that if the value of relating rises by 1 point while the other variables remain, then the value of customer loyalty will decrease by -0.011953 points. And vice versa, if relate value drops by 1 point while the other variables remain, then customer loyalty will increase by -0.011953 points.

\section{Hypothesis Testing}

\section{T-test}

This hypothesis test is conducted to determine the presence/absence of the influence of the independent variable with the dependent variable partially. The results of the analysis between the independent variables, which consist of sense, feel, think, act and relate to the dependent variable, namely customer loyalty, using the Eviews 7 program, the calculation results are obtained.

From the results of calculations for the $\mathrm{t}_{\text {test }}$ of sense variables obtained a $\mathrm{t}_{\text {count }}$ of 3.629307 with a probability of 0.0005 . The basis of decision making for sense variable is $\mathrm{H}_{0}$ : There isn't a sense effect on Excelso cafe customer loyalty in Central Jakarta 2019 and $\mathrm{H}_{1}$ : There is a sense effect on Excelso cafe customer loyalty in Central Jakarta 2019. By using that basic decision, it is known based on the twosided distribution table at $\mathrm{df}=(\mathrm{NK})$ or $100-6=94$ with $\alpha_{(0.05)}$, the value of t table is 1.98552 , it can be concluded that $\mathrm{t}_{\text {count }}(3.629307)>\mathrm{t}_{\text {table }}(1.98552)$, which means rejecting $\mathrm{H}_{0}$ and accepting $\mathrm{H}_{1}$. So the first hypothesis proposed states that there is an effect of sense on Excelso cafe customer loyalty in 2019, can be accepted.

The following calculations for the $\mathrm{t}_{\text {test }}$ of feel variable obtained a $\mathrm{t}_{\text {count }}$ of 3.012798 with a probability of 0.0033 . The basis for decision making for feel variable is $\mathrm{H}_{0}$ : There isn't a felt effect on Excelso cafe customer loyalty in Central Jakarta in 2019 and $\mathrm{H}_{1}$ : There is a felt effect on Excelso cafe customer loyalty in Central Jakarta 2019. By using that basic decision, it is known based on the twosided distribution table at $\mathrm{df}=(\mathrm{N}-\mathrm{K})$ or $100-6=94$ with $\alpha_{(0.05)}$, the value of $\mathrm{t}_{\text {table }}$ is 1.98552. Then it can be concluded $t_{\text {count }}$ (3.012798) $>t_{\text {table }}$ (1.98552), which means reject $\mathrm{H}_{0}$ and accept $\mathrm{H}_{1}$. So that the second hypothesis proposed states that there is an effect of feeling on Excelso cafe customer loyalty in Central Jakarta 2019, can be accepted.

The following calculations for the $t_{\text {test }}$ of think variable obtained a $t_{\text {count }}$ of 3.395759 with a probability of 0.0010 . The basis for decision making for think variable is $\mathrm{H}_{0}$ : There isn't a thought effect on Excelso cafe customer loyalty in Central Jakarta 2019 and $\mathrm{H}_{1}$ : There is a thought effect on Excelso cafe customer loyalty in Central Jakarta 2019. By using that basic decision, it is known based on the two-sided distribution table at $\mathrm{df}=(\mathrm{N}-\mathrm{K})$ or $100-6=94$ with $\alpha_{(0.05)}$, the value of $\mathrm{t}$ table is 1.98552. Then it can be concluded $\mathrm{t}_{\text {count }}(3.395759)>\mathrm{t}_{\text {table }}(1.98552)$, which means reject $\mathrm{H}_{0}$ and accept $\mathrm{H}_{1}$. So the third hypothesis proposed states that there is an effect of think on Excelso cafe customer loyalty in Central Jakarta 2019, can be accepted. 
The following calculations for the $\mathrm{t}_{\text {test }}$ of the act variable obtained a $\mathrm{t}_{\text {count }}$ of 1.461016 with a probability of 0.1473 . The basis for decision making for act variable is $\mathrm{H}_{0}$ : There isn't an active effect on Excelso cafe customer loyalty in Central Jakarta 2019 and $\mathrm{H}_{1}$ : There is an active effect on Excelso cafe customer loyalty in Central Jakarta 2019. By using that basic decision, it is known based on the two-sided distribution table at $\mathrm{df}=(\mathrm{N}-\mathrm{K})$ or $100-6=94$ with $\alpha_{(0.05)}$, the value of $\mathrm{t}_{\text {table }}$ is 1.98552 . Then it can be concluded $\mathrm{t}_{\text {count }}(1.461016)>\mathrm{t}_{\text {table }}(1.98552)$, which means reject $\mathrm{H}_{0}$ and accept $\mathrm{H}_{1}$. So that the fourth hypothesis proposed states that there is an effect of the act on Excelso cafe customer loyalty in Central Jakarta 2019, can be accepted.

Furthermore, the calculation results for the t-test of related variables obtained $\mathrm{t}_{\text {count }}$ of -0.189031 with a probability of 0.8505 . The basis for decision making for the related variable is $\mathrm{H}_{0}$ : There isn't a related effect on Excelso cafe customer loyalty in 2019 and $\mathrm{H}_{1}$ : There is a related effect on Excelso cafe customer loyalty in Central Jakarta 2019. By using that basic decision, it is known based on the twosided distribution table at $\mathrm{df}=(\mathrm{N}-\mathrm{K})$ or $100-6=94$ with $\alpha_{(0.05)}$, the value of $\mathrm{t}_{\text {table }}$ is 1.98552. Then it can be concluded that $\mathrm{t}_{\text {count }}(-0.189031)<\mathrm{t}_{\text {table }}(1.98552)$, which means it failed to reject $\mathrm{H}_{0}$ so that the fifth hypothesis proposed states that there is an effect of relating on Excelso cafe customer loyalty in Central Jakarta in 2019, is unacceptable.

$\mathbf{F}_{\text {test }}$

$\mathrm{F}_{\text {test }}$ is used to determine the effect of independent variables, in this case, are sense, feel, think, act, and relate together to the dependent variable customer loyalty. From the results of calculations, it can be seen that the results of the $\mathrm{F}_{\text {count }}$ test are 48.24063 with a probability of 0.000000 . The basis for decision making for the $\mathrm{F}_{\text {test }}$ is $\mathrm{H}_{0}$ : There aren't effect of sense, feel, think, act and relate together on Excelso cafe customer loyalty in Central Jakarta in 2019 and $\mathrm{H}_{1}$ : There is the effect of Sense, Feel, Think, Act and Relate Together on Excelso cafe customer loyalty in Central Jakarta in 2019. By using that basic decision, it is known based on $\mathrm{F}_{\text {table }}$ with df $=(\mathrm{K}-1, \mathrm{~N}-\mathrm{K})=(6-1),(100-6)=5.94$ with $\alpha_{(0.05)}$, the $\mathrm{F}_{\text {table }}$ value of 2.31 is obtained. Then it can be concluded $\mathrm{F}_{\text {count }}(48.24063)>\mathrm{F}_{\text {table }}(2.31)$, which means reject $\mathrm{H}_{0}$ and accept $\mathrm{H}_{1}$. So that the sixth hypothesis proposed states that there are effects of Sense, Feel, Think, Act, and Relate Together with customer loyalty Excelso cafe in Central Jakarta in 2019, can be accepted.

\section{Coefficient of Determination}

The coefficient of determination $\left(\mathrm{R}^{2}\right)$ is essential to measure how far the ability of the model in explaining the dependent variable (Nathaniel, 2008). From the calculation results obtained by the magnitude effect of the independent variables on the dependent variable that can be explained by the model in this equation is 0.719573 or $71.96 \%$. This shows that the variations of Sense, Feel, Think, Act and Relate can explain variations in the rise/fall of customer loyalty by $71.96 \%$, while the remaining $28.04 \%$ is explained by other factors beside sense, feel, think, act and relate that are not included in this regression model. 


\section{E. CONCLUSION}

Conclusions that can be drawn from the results of research The Effect of Experiential Marketing on Excelso cafe Customer Loyalty in Central Jakarta 2019 are Excelso cafe customers in Central Jakarta stated that experiential marketing of sense effect on Excelso cafe customer loyalty in Central Jakarta in 2019. This is due to attractive design and interior, the coolness of the atmosphere that makes respondents comfortable, food and drinks that have a taste that suits the taste of the respondent, and music that makes the respondent feel at home, therefore the five senses through sound, touch, sight, and smell give a very positive and significant effect on customer loyalty, so customers make the sense as a consideration to determine customer loyalty as a customer commitment perseveres deeply in Excelso cafe Central Jakarta.

Experiential marketing of feel effect on Excelso cafe customer loyalty in Central Jakarta 2019. This is because employees are friendly, the speed of presentation is given, the accuracy in the presentation provided, and respondents felt impressed while in Excelso cafe Central Jakarta, therefore the feel created include feelings and emotions to make customers return and enjoy the dishes provided by Excelso cafe so that customers make feel as consideration to determine Excelso cafe customer loyalty in Central Jakarta. Experiential Marketing of think effect on Excelso cafe customer loyalty in Central Jakarta 2019. This is because of an event to entertain, customers can enjoy everything innovation through the variety of menus offered, and the unique layout, and strategic and easily accessible location, so Excelso cafe Central Jakarta makes customers want to come back and enjoy the food and drinks provided.

Experiential Marketing of acts effect on Excelso cafe customer loyalty in Central Jakarta 2019. This is because customers are interested in trying a variety of food and other beverage menus that are offered Excelso cafe Central Jakarta which is the most suitable place to gather and relax with family and friends, the service is following the needs of consumers, and the products offered are of high quality so that customers make act as a consideration to determine Excelso cafe customer loyalty in Central Jakarta in 2019. Experiential Marketing of relates less effect on Excelso cafe customer loyalty in Central Jakarta 2019. This is because all the community didn't make Cafe Excelso Central Jakarta as a gathering place with family, friends, and relationships, because of the many places to eat and hangout more comfortably.

Based on this study illustrates that experiential marketing affects Excelso cafe customer loyalty in Central Jakarta 2019. For Excelso cafe in Central Jakarta, this research gives an illustration that sense, feel, think, act, and relationships must be improved so that customers can have a high attitude of loyalty. Furthermore, those who wish to examine experiential marketing in a company are expected to conduct further and in-depth research related to the effect of experiential marketing on customer loyalty with the same research methods and different companies for the wider applicability of these findings, as well as adding other variables can increase the effect of customer loyalty. 


\section{REFERENCES}

Alkilani, K., Ling, K. C., \& Abzakh, A. A. (2013). The impact of experiential marketing and customer satisfaction on customer commitment in the world of social networks. Asian Social Science, 9(1), 262.

Buchari, A. (2014). Marketing and Service Marketing Management. Alfabeta: Bandung.

Chen, S.-C. (2012). The customer satisfaction-loyalty relation in an interactive eservice setting: The mediators. Journal of Retailing and Consumer Services, 19(2), 202-210.

Gee, R., Coates, G., \& Nicholson, M. (2008). Understanding and profitably managing customer loyalty. Marketing Intelligence \& Planning.

Griffin, C. L. (2008). Loyalty is defined as non random purchase expressed over time by some decision making unit. Berdasarkan definisi tersebut dapat dijelaskan bahwa loyalitas lebih mengacu ....

Halim, P., Swasto, B., Hamid, D., \& Firdaus, M. R. (2014). The influence of product quality, brand image, and quality of service to customer trust and implication on customer loyalty (survey on customer brand sharp electronics product at the South Kalimantan Province). European Journal of Business and Management, 6(29), 159-166.

https://excelso-coffee.com/about-us/. (n.d.). No Title. https://excelsocoffee.com/about-us/

Iglesias, O., Singh, J. J., \& Batista-Foguet, J. M. (2011). The role of brand experience and affective commitment in determining brand loyalty. Journal of Brand Management, 18(8), 570-582.

Kertajaya, H. (2010). Grow with character: The model marketing. Jakarta: PT. Gramedia Pustaka Utama, 13.

Kotler, P. T. (2019). Marketing management. Pearson UK.

Munandar, D. (2011). Customer Relationship Management Terhadap Loyalitas Pelanggan Bisnis PT. Frisian Flag Indonesia Bandung. Majalah Ilmiah Unikom.

Oliver, R. L. (2010). Consumer brand loyalty. Wiley International Encyclopedia of Marketing.

Rahardja, C., \& Anandya, D. (2010). Experiential marketing, customer satisfaction, behavioral intention: timezone game center Surabaya.

Rizal, M. (2016). Pengaruh Experiential Marketing terhadap Loyalitas Pelanggan Kolam Renang Mutiara Waterpark Perumnas Langsa. Jurnal Manajemen Dan Keuangan, 5(1), 469-478.

Schmitt, B. (2011). Experience marketing: Concepts, frameworks, and consumer insights. Now Publishers Inc.

Sugianto, J., \& Sugiharto, S. (2013). Analisa pengaruh service quality, food quality, dan price terhadap kepuasan pelanggan restoran Yung Ho Surabaya. Jurnal Manajemen Pemasaran, 1(2), 1-10.

Sugiyono, P. D. (2017). Metode Penelitian Bisnis: Pendekatan Kuantitatif, Kualitatif, Kombinasi, dan R\&D. Penerbit CV. Alfabeta: Bandung.

Tsai, M.-T., Tsai, C.-L., \& Chang, H.-C. (2010). The effect of customer value, 
customer satisfaction, and switching costs on customer loyalty: An empirical study of hypermarkets in Taiwan. Social Behavior and Personality: An International Journal, 38(6), 729-740.

Walter, N., Cleff, T., \& Chu, G. (2013). Brand experience's influence on customer satisfaction and loyalty: a mirage in marketing research. International Journal of Management Research and Business Strategy, 2(1), 130-144.

Yusuf, A. M. (2016). Metode penelitian kuantitatif, kualitatif \& penelitian gabungan. Prenada Media.

Zichermann, G., \& Linder, J. (2010). Game-based marketing: inspire customer loyalty through rewards, challenges, and contests. John Wiley \& Sons. 